\title{
FINANCIAL MANAGEMENT PRACTICES IN SUCCESSFUL SMALL AND MEDIUM ENTERPRISES (SMEs)
}

Hendrik Wolmarans

hendrik.wolmarans@up.ac.za

Quentin Meintjes

gmcape@gmail.com

University of Pretoria

\section{ABSTRACT}

Although the success of small, medium and micro enterprises (SMEs) is extremely important for the South African economy, their failure rate is amongst the highest in the world; some researchers estimate as high as 90 percent. Research has shown that the lack of financial management skills and application of financial management practices are some of the biggest factors contributing to SME failure. However, it is not clear from the literature which of these skills and practices are more important than others. This study aims to fill this gap by determining which financial management skills are relevant for successful SMEs. A survey was done on a sample of owner-managers of successful SMEs who had been asked, firstly, whether they performed different financial management practices and, secondly, how frequently they performed these in their companies. The study concludes that practices regarding working capital as well as profitability are much more relevant than those regarding a balance sheet or strategic finance. Similarly, financial practices related to cash flow and decision making are more relevant than those related to planning or analysing. It may be true, due to the high risk and volatile environment of SMEs, as well as the challenges that are often underestimated, that financial practices which academics regard as important are not always implemented by these companies. This study contributes to the existing body of knowledge as it determines the relative relevance and frequency of use of financial management practices by successful SMEs.

\section{KEY WORDS}

Small and medium enterprises, Financial management practices, Successful SMEs, Entrepreneurship education 


\section{INTRODUCTION}

Various studies have identified the performance of a country's SME sector as a good indicator of its overall vitality and future prospects (Xesha, Iwu \& Slabbert, 2014:37). Small businesses are globally regarded as being important for the income, growth and prosperity of individuals, the community and the economy (Badenhorst-Weiss \& Cilliers, 2014:2; Nkosi, Bounds \& Goldman, 2013:1). In the European Union, SMEs are even seen as the engine for societal development, as apart from the obvious contributions they make toward the gross domestic product (GDP), they are, inter alia, a source of employment and training for the youth (Nkosi, Bounds \& Goldman, 2013:1).

The activities of the SME sector in Africa are crucial for promoting economic growth, job creation and poverty alleviation (Rogerson, 2001a:267), while the small business sector is often seen as the incubator of employment, innovation and growth (Carter \& Van Auken, 2006:493). Steyn and Leonard (2012:24) even see SMEs as the driving force of any economy. However, in spite of various incentives, training programmes and research by academics, Olawale and Smit (2010:1790) estimate that as many as 75 percent of South African SMEs eventually fail. Some researchers even estimate this failure rate to be as high as 90 per cent (Radipere \& Van Scheers, 2005:402, Pretorius, 2009:1). This failure rate is one of the highest in the world. As a comparison the average failure rate for SMEs in 21 European countries in 2010 was only 35 percent (Marzocchi, Ramlogan \& Gagliardi 2013:23).

There is consensus amongst experts that financial management skills are some of the key components in the skills mix for SMEs to be successful (Bloom \& Boessenkool, 2002:244, Roodt, 2005:18, Kotze \& Smit, 2008:35, Akande, 2011:372, Bezuidenhout \& Nenungwe, 2012:11658). If an SME is not managed well from a financial management point of view, it cannot survive over the medium- to long-term. However, what is not yet clear from the literature is which specific financial management practices are more important in successful SMEs. Which of the numerous financial management skills have the owner-managers of successful SMEs found to be most useful? Which of the financial management practices do they use most frequently? 
This study seeks to answer these questions. This knowledge could be important not only for existing and nascent (aspiring) entrepreneurs, but also for educators of future owner-managers of small firms. In enhancing the ways in which financial management knowledge can be utilised in practice by owner-managers of SMEs, the results of this study can also contribute to the enhancement of the success of SMEs in South Africa. The aim of this study is to determine the relative relevance to and frequency of use of specific financial management practices as performed by the owner-managers of successful SMEs in the Western Cape.

A survey was done on the owner-managers of 30 successful SMEs in the Western Cape. The results indicate that the financial management practices that SME ownermanagers regard as relevant and are performed more than once a quarter, tend to focus more on working capital and profitability than on the balance sheet or strategic finance. Similarly, practices related to cash flow and decision-making are regarded as more valuable than those related to planning or analysing. The layout of this article is as follows: the literature review is followed by a discussion on what makes an SME successful. Specific financial management practices are then linked to financial management skills. Next, a profile of the Western Cape is given, followed by the hypotheses and research methodology. The results then follow, where-after conclusions and recommendations are made and possible future research areas identified.

\section{LITERATURE REVIEW}

In common with the experience of many countries in the developing world, postapartheid South Africa has been at the forefront of the development and implementation of a set of pro-SME policies (Rogerson, 2001b:271). The promotion of SMEs has been recognised by the South African government as one of the key pillars of economic strategies for reconstruction and development in post-apartheid South Africa. The monitoring of research on the SME economy in South Africa is viewed as a critical issue of high policy relevance (Rogerson, 2008:35). SMEs are critical in the economic and social development of most countries (Sanda, Sackey \& Fältholm, 2011:7). They are especially important for their role in job creation with low investment, development of entrepreneurship, regional development, and as 
suppliers to large companies. However, despite their important contribution to economic vitality, small firms often experience financial stress (Carter \& Van Auken, 2006:493).

\section{The definition of SMEs}

Internationally an SME is defined by the annual turnover and the number of full-time employees in the firm (World Bank, 2011:4). The Asia-Pacific Economic Cooperation (APEC) indicates that in APEC's participating countries an SME normally will have not more than 100 employees (Liang, 2003:173). To qualify as an SME in South Africa, a firm should have not more than 50 employees and a turnover of less than R64 million (South Africa, 1996). However, the new small business corporation tax aimed at SMEs, includes all firms with an annual turnover of less than R14 million (Burger, 2009:4). For this study the target population is, therefore, all SMEs with a turnover of less than R14 million that employ fewer than 50 full-time employees.

\section{Failure and sustainability of SMEs}

SMEs in South Africa are more likely to fail than to succeed. Van Eeden, Viviers and Venter (2003:13) estimated the failure rate of South African SMEs to be between 70 and 80 percent. Olawale and Garwe (2010:730) and Mutezo (2013:153) were of the opinion that 75 percent of new SMEs in South Africa will never become established firms. Radipere and Van Scheers (2005:402) estimated this failure rate to be as high as 90 percent. When South Africa is compared internationally, the failure rate of South African SMEs is extremely high.

In South Africa, whereas as few as 19 percent of adults intend to become entrepreneurs, only 2.3 percent (of adults) eventually become the owners of established businesses (Turnton \& Herrington, 2012:53). This rate is one of the lowest and far below the average of eight percent for similar countries.

While new business owners in the UK generally open their businesses flush with optimism at their chances of success, more than 50 percent of them fail in the first two- and- a- half years of trading (Dennis and Fernald, 2001:75; Cressy, 2006:103). In South Africa Radipere and Van Scheers (2005:402) estimate that 40 percent of 
small firms fail in their first year, 60 percent before their second year has passed and 90 percent in their first 10 years of existence. Adeniran and Johnson (2012:4088) estimated that South African SMEs fail at a rate of between 70 and 80 percent. Pretorius (2009:1) estimated this rate to be between 50 and 90 percent.

The sustainability of an SME is generally linked to the period that it actively trades in the market. Young firms tend to be more prone to failure than older ones (Cressy, 2006:103). Knaup and Piazza (2007:7) found that, if the age of an SME is less than one year, it has only a $31 \%$ probability of surviving for seven or more years (see Figure 1). On the other hand, if an SME has already survived for four years the probability of lasting three more years (in total, then, seven years) increases significantly to 70 percent. Only after seven years do these authors regard the SME to be well established.

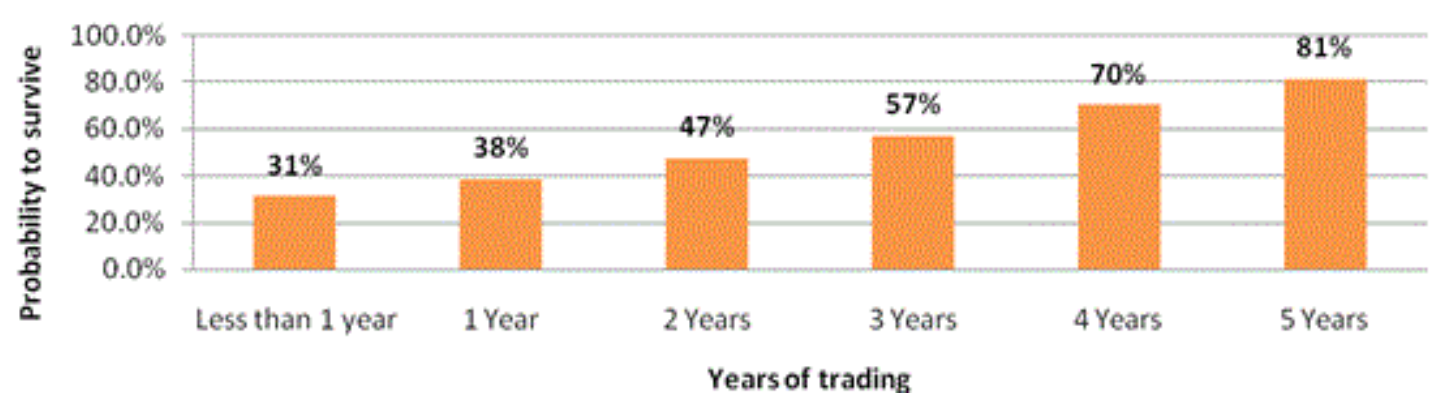

Figure 1: Age of the SME and probability of surviving for seven or more years (Source: Adapted from Knaup \& Piazza, 2007:7)

Von Broembsen, Wood and Herrington (2005:20) were of the opinion that South African and Mexican start-up firms are the least likely of their international counterparts to survive for more than 42 months (three and a half years). Olawale and Garwe (2010:730) defined a SME that has been in existence for more than 42 months, as an established SME, as the risk of failure reduces significantly after this time period. For the purpose of this study it is assumed that a sustainable SME is one that has traded for at least 42 months. 


\section{South African studies}

A number of South African studies similar to this one have been done on various financial aspects of SMEs. The titles of these studies, the research design and the sample sizes are summarised in Table 1.

\section{Table 1: Sample size of related studies}

\begin{tabular}{|c|c|c|c|c|}
\hline Researcher & Year & Title & Research design & $\begin{array}{l}\text { Sample } \\
\text { Size }\end{array}$ \\
\hline $\begin{array}{l}\text { Van Eeden, } \\
\text { Viviers \& } \\
\text { Venter }\end{array}$ & 2003 & $\begin{array}{l}\text { A comparative study of selected } \\
\text { problems encountered by small } \\
\text { businesses in the Nelson } \\
\text { Mandela, Cape Town and Egoli } \\
\text { metropoles }\end{array}$ & $\begin{array}{l}\text { Survey research } \\
\text { (non-probability } \\
\text { sampling) }\end{array}$ & 1036 \\
\hline Schwarze & 2008 & $\begin{array}{l}\text { Involving the accounting } \\
\text { profession in the development } \\
\text { of financial management skills } \\
\text { of micro-enterprise owners in } \\
\text { South Africa }\end{array}$ & $\begin{array}{l}\text { Survey research } \\
\text { (non-probability } \\
\text { sampling) }\end{array}$ & 8 \\
\hline $\begin{array}{l}\text { Rajaram \& } \\
\text { O'Neill }\end{array}$ & 2009 & $\begin{array}{l}\text { Profit or no profit - does the } \\
\text { SME sector really know? }\end{array}$ & $\begin{array}{l}\text { Survey research } \\
\text { (non-probability } \\
\text { sampling) }\end{array}$ & 30 \\
\hline Ligthelm & 2010 & $\begin{array}{l}\text { Entrepreneurship and small } \\
\text { business sustainability }\end{array}$ & $\begin{array}{l}\text { Survey research } \\
\text { (probability } \\
\text { sampling) }\end{array}$ & 300 \\
\hline $\begin{array}{l}\text { Olawale \& } \\
\text { Smit }\end{array}$ & 2010 & $\begin{array}{l}\text { The impact of the business } \\
\text { environment on the availability } \\
\text { of trade credit to new SMEs in } \\
\text { South Africa }\end{array}$ & $\begin{array}{l}\text { Survey research } \\
\text { (probability } \\
\text { sampling) }\end{array}$ & 233 \\
\hline $\begin{array}{l}\text { Rootman \& } \\
\text { Kruger }\end{array}$ & 2010 & $\begin{array}{llr}\text { Adapting } & \text { SMME } & \text { business } \\
\text { functions } & \text { during } & \text { economic } \\
\text { turmoil. } & & \\
& & \end{array}$ & $\begin{array}{l}\text { Survey research } \\
\text { (non-probability } \\
\text { sampling) }\end{array}$ & 250 \\
\hline $\begin{array}{l}\text { Nkosi, } \\
\text { Bounds \& } \\
\text { Goldman }\end{array}$ & 2013 & $\begin{array}{l}\text { Skills required for the } \\
\text { management of Black-owned } \\
\text { small enterprises in Soweto. }\end{array}$ & $\begin{array}{l}\text { Survey research } \\
\text { (non-probability } \\
\text { sampling) }\end{array}$ & 25 \\
\hline $\begin{array}{l}\text { Badenhorst- } \\
\text { Weiss \& } \\
\text { Cilliers }\end{array}$ & 2014 & $\begin{array}{l}\text { Competitive advantage of } \\
\text { small businesses in Soweto. }\end{array}$ & $\begin{array}{l}\text { Survey research } \\
\text { (multi stage quota } \\
\text { sampling) }\end{array}$ & 497 \\
\hline
\end{tabular}

Van Eeden et al. (2003:44) endeavoured to establish to what extent small businesses in a typical South African setting experienced selected problems as negatively influencing the success of their business. The most prominent problem areas were economic and financial factors, competition, socio-economic problems 
and change. Schwarze (2008:139) found that most SME owners do not possess the critical financial management skills required to ensure survival and growth of their enterprises. Rajaram and O'Neill (2009:115) determined that the SME sector in KwaZulu-Natal did, on average, not possess the accounting and financial management skills needed to function optimally and reach their full potential with regard to profitability, growth and sustainability.

Ligthelm (2010:131) determined that entrepreneurial acumen, business and financial management skills can be classified as the strongest predictors of small business survival. Olawale and Smit (2010:1778) investigated the impact of the business environment (internal and external environment) on the availability of debt from commercial banks to new SMEs. Internal factors were labelled as managerial competencies, collateral, networking and business information, which were important. The external factors were labelled macro-economy, legal, ethics, crime and corruption. Results showed that both internal and external factors have a significant impact on the availability of debt to new SMEs.

Rootman and Kruger (2010:107) investigated how SMEs should adapt their business function to improve business performance during times of economic turmoil. Respondents regarded the financial management function as the area in SMEs that required the most focus and adjustment, to improve business performance during challenging economic times. Nkosi, Bounds \& Goldman (2013:1) sought to identify the most pertinent business and management skills required for the management of small enterprises in Soweto. The findings indicated that most SME owners lack management and business skills and that SME owners often seem to be driven by non-monetary rewards.

Badenhorst-Weiss and Cilliers (2014:1) explored the various sources of competitive advantage, focusing specifically on differentiation (also in price) and a unique value package to ensure competitiveness and sustainability for independent small businesses in Soweto. It was found that sustainable small businesses use the elements of their value packages better than stagnating or shrinking businesses. 
From the literature reviewed above it can be deduced that SMEs, although very important for the South African economy in terms of creation of both job opportunities and wealth, continue to have a high failure rate. It is also apparent that financial management practices are necessary for SME survival, growth and success. However, no research has yet investigated the relative value of different financial management practices among the owner-managers of SMEs, nor how frequently these practices are performed.

\section{DEFINITIONS}

Different concepts should be clearly defined and distinguished. Accounting can be defined as the systematic and comprehensive recording of financial transactions pertaining to a business (Brigham \& Houston, 2011). The primary objective of financial accounting is the preparation of financial statements - including the balance sheet, income statement and cash flow statement - that encapsulates the company's operating performance over a particular period, and financial position at a specific point in time. Cost accounting entails the recording of all the costs incurred in a business in a way that can be used to improve its management. Financial management, on the other hand, can be defined as the planning, directing, monitoring, organizing, and controlling of the monetary resources of an organization.

It is clear that these concepts may overlap, but for an SME owner the differences may be much less obvious. However, the skill-set required for each of the disciplines of accounting and financial management are not necessarily the same. For example, an SME owner might not know how to prepare an income statement, but might be able to interpret its results.

\section{SUCCESSFUL SMES}

The success of a firm is normally measured by its financial performance (profits, return on assets, and return on investment); product market performance (sales or market share) or shareholders' returns (Richard, Devinney, Yip \& Johnson, 2009:722). Traditionally, SMEs are also typically expected to aim at growth over time (Berger \& Udell, 1998:613). However, what an owner-manager of an SME defines as success for an SME could differ. Subjective factors such as personal satisfaction, 
work-life balance, customer satisfaction, employee satisfaction, and usefulness are often seen as more important than financial performance (Gorgievski, Ascalon and Stephan, 2011:222). Dennis and Fernald (2001:75) found that only 17 percent of the owners of new SMEs had as their aim to start a profitable venture which would improve the owner's financial standing.

LeCornu, McMahon, Forsaith and Stanger (1996:1) and Walker and Brown (2004:577) agreed that entrepreneurs often define success more in terms of nonfinancial factors. In spite of the above, there are strong indications in the literature that if SMEs are not managed well from a financial point of view, they will not continue to be successful (Collis \& Jarvis, 2002:100; Carter \& Van Auken, 2006:493; Cressy, 2006:103; Rajaram \& O’Neill, 2009:99).

\section{External and internal factors related to the failure of SMEs}

The factors that contribute to the failure of SMEs can be classified into external and internal factors. External factors are those that cannot be controlled by the ownermanager, such as the macroeconomic environment, social factors such as crime, ethics and corruption, technology and the regulatory environment (Olawale \& Garwe, 2010:732). Internal factors within the SME are factors which can be controlled by the SME, such as access to finance, geographic location and the level of managerial skills in the SME. As Figure 2 indicates, Canadian SMEs that fail due to internal factors predominately fail due to the lack of general management and financial management skills (Statistics Canada 1997:24).

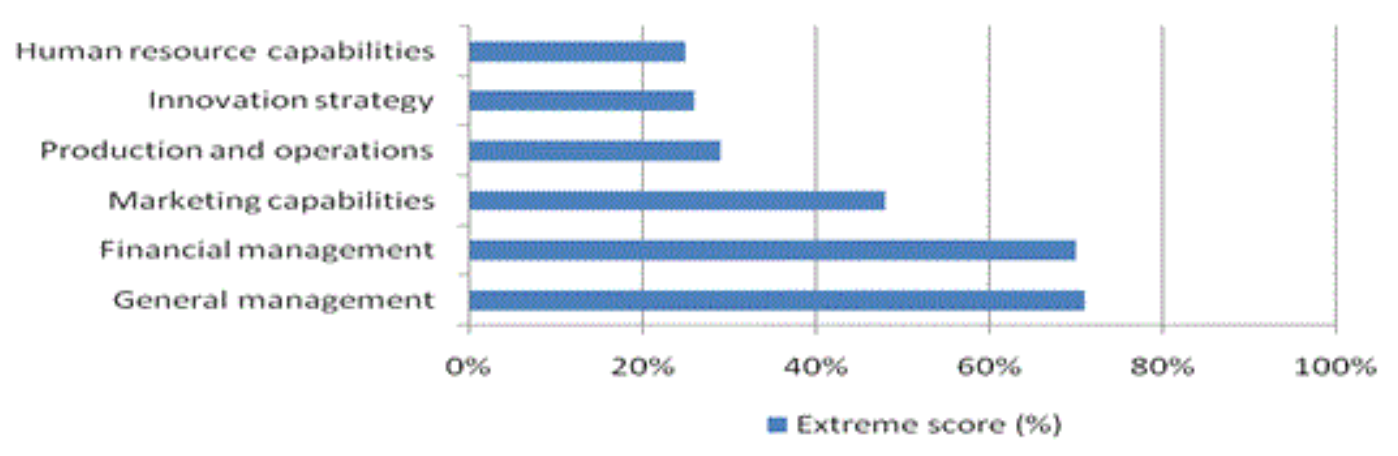

Figure 2: The importance of internal factors causing bankruptcy

(Source: Adapted from Statistics Canada 1997:24) 
From Figure 2 it seems that a lack of financial management skills is more than twice as likely to cause financial failure than a lack of operations or human resource skills. It is evident that financial management skills are some of the cornerstone skills for successful SMEs. Olawale and Smit (2010:1790) agree that, for South African entrepreneurs, the lack of financial management skills is one of the most important inhibiting internal factors.

\section{SME success and the use of financial information}

How strong is the correlation between the use of financial information and success of SMEs? Mixed results have been found by different researchers. For SMEs in the USA, McMahon and Davies (1994:15) did not find a significant correlation between more comprehensive historical financial reporting and the use of financial ratios on the one hand and the SME's rate of growth and financial performance on the other. Thomas and Evanson (1987:570) found no relationship between the use of financial ratios and the success of small pharmaceutical firms in the UK. However, they argued that this may be due to a lack of sophistication in the use of these ratios.

Akande (2011:372) confirmed that accounting and financial management skills are important for entrepreneurs and advise small business owner-managers to embark on capacity building in these disciplines. Roodt (2005:18) found that financial skills are some of the top skills that entrepreneurs report as necessary for success in business.

Financial management is one of the most important management skills for an SME because it affects every aspect of the entrepreneurial venture (Watson, 2004:88). Financial management entails minimising the costs, maximising the profit, and planning and controlling the financial assets of the firm (Bloom \& Boessenkool, 2002:244).

Collis and Jarvis (2002:100) investigated the use of financial information by small companies in the UK and found that the majority of small companies adopt practices that include formal planning and control. Everett and Watson (1998:372) argued that SMEs cannot be successful without sufficient funding and adequate management skills. However, the funding obtained can often be linked to the level of financial 
management skills present within the SME. Olawale and Garwe (2010:736) proposed that new SMEs should be able to draw up business plans, have strategic and operational plans and forecast cash flows to secure debt, actions which are mostly the result of advanced financial management skills. Without these key outputs, credit providers are hesitant to provide funding to SMEs.

From the above it can be postulated that financial management skills are indispensable to successful SMEs. Benzing, Chu and Kara (2009:86), Rootman and Kruger (2010:107) and Ligthelm (2010:131) agree. In spite of all the reasons why financial management skills and practices are regarded as indispensable for SME success, very few researchers have investigated which specific of these practices are the most relevant for entrepreneurs. However, financial management practices could first be grouped into logical groups and linked to financial topics and financial skills.

\section{LINKING SPECIFIC FINANCIAL MANAGEMENT PRACTICES TO FINANCIAL MANAGEMENT TOPICS AND TO FINANCIAL MANAGEMENT SKILLS}

In order to understand the scope of financial management practices more fully, it is useful to link these practices to established financial management topics and financial management skills. Chandra (2008) raises five main topics relating to SMEs:

- $\quad$ cost and management accounting;

- financial analysis and planning;

- $\quad$ investment decision;

- $\quad$ financing decision; and

- $\quad$ working capital management.

Brigham and Houston (2011:4) and Moyer, McGuigan and Kretlow (2012:23) list various financial management practices which are important for SMEs. In Table 2 these practices are linked to the financial management topics. For instance, the 
interpretation of an income statement is more related to the topic of financial analysis and planning than to other topics.

Table 2: SME financial management practices linked to financial management topics

\begin{tabular}{|c|c|c|c|c|c|}
\hline \multirow[b]{2}{*}{ Financial Management Practice } & \multicolumn{5}{|c|}{ Financial management topic } \\
\hline & 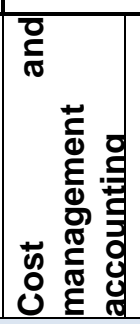 & 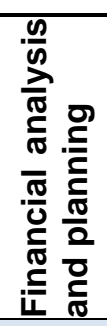 & 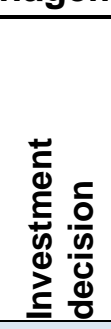 & 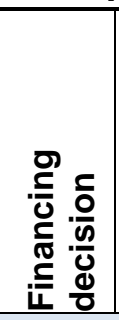 & 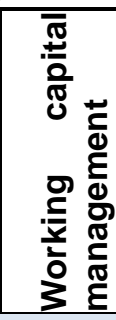 \\
\hline \multicolumn{6}{|l|}{ Profitability management } \\
\hline Interpret income statement & & $\sqrt{ }$ & & & \\
\hline Prepare tax returns & & $\sqrt{ }$ & & & \\
\hline Prepare forecasted income statement & $\sqrt{ }$ & $\sqrt{ }$ & $\sqrt{ }$ & & \\
\hline Analyse forecasted variance on income statement & $\sqrt{ }$ & $\sqrt{ }$ & & & \\
\hline Prepare break-even analysis & $\sqrt{ }$ & $\sqrt{ }$ & $\sqrt{ }$ & & \\
\hline Prepare segmented income statement & $\sqrt{ }$ & $\sqrt{ }$ & $\sqrt{ }$ & & \\
\hline \multicolumn{6}{|l|}{ Working capital management } \\
\hline Prepare list of all debtors & & & & & $\sqrt{ }$ \\
\hline Assess the levels of stock of the business & & & & & $\sqrt{ }$ \\
\hline Prepare list of all creditors & & & & & $\sqrt{ }$ \\
\hline Prepare cash flow statement & & & & & $\sqrt{ }$ \\
\hline Prepare forecasted cash flow statement & $\sqrt{ }$ & $\sqrt{ }$ & $\sqrt{ }$ & $\sqrt{ }$ & $\sqrt{ }$ \\
\hline Analyse cash flow statement using previous periods as a base & & $\sqrt{ }$ & $\sqrt{ }$ & $\sqrt{ }$ & $\sqrt{ }$ \\
\hline Budget/Forecast Variance analysis on cash flow statement & & $\sqrt{ }$ & $\sqrt{ }$ & $\sqrt{ }$ & $\sqrt{ }$ \\
\hline Analyse bank statements using previous periods as a base & & & & $\sqrt{ }$ & $\sqrt{ }$ \\
\hline \multicolumn{6}{|l|}{ Asset and liability management } \\
\hline Prepare balance sheet & & $\sqrt{ }$ & & & $\sqrt{ }$ \\
\hline Prepare forecasted balance sheet & & $\sqrt{ }$ & $\sqrt{ }$ & $\sqrt{ }$ & \\
\hline Analyse balance sheet using previous periods as a base & & $\sqrt{ }$ & $\sqrt{ }$ & $\sqrt{ }$ & \\
\hline Budget/Forecast variance analysis on balance sheet & & $\sqrt{ }$ & $\sqrt{ }$ & $\sqrt{ }$ & \\
\hline Analyse key financial ratios in the business & & $\sqrt{ }$ & $\sqrt{ }$ & $\sqrt{ }$ & $\sqrt{ }$ \\
\hline \multicolumn{6}{|l|}{ Strategic financial management } \\
\hline Prepare business plans & $\sqrt{ }$ & $\sqrt{ }$ & $\sqrt{ }$ & $\sqrt{ }$ & $\sqrt{ }$ \\
\hline Perform scenario analysis \& planning & $\sqrt{ }$ & $\sqrt{ }$ & $\sqrt{ }$ & $\sqrt{ }$ & $\sqrt{ }$ \\
\hline
\end{tabular}

(Source: own contribution) 
From Table 2 it can be seen that various financial management topics, from accounting to working capital management, all play an important role in the successful management of a company and have financial practices associated with them which sometimes overlap. Rajaram and O'Neill (2009:111) and Schwarze (2008:145) identify four categories of financial management skills, namely cash flow management, decision making, planning and analysis. Linking the financial management practices to specific financial management skills could be useful to determine which category of financial management skills is more important, on average, for the owner-managers of SMEs. In Table 3, the financial management practices are linked to the financial management skills as identified by Rajaram and O’Neill (2009:111) and Schwarze (2008:145).

Table 3: Financial management practices linked to financial management skills

\begin{tabular}{|c|c|c|c|c|}
\hline \multirow[b]{2}{*}{ Financial Management Practice } & \multicolumn{4}{|c|}{$\begin{array}{c}\text { Financial management } \\
\text { skills }\end{array}$} \\
\hline & 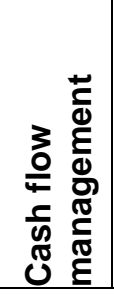 & 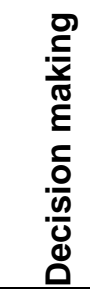 & 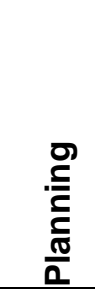 & 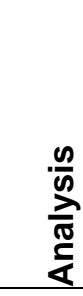 \\
\hline \multicolumn{5}{|l|}{ Profitability management } \\
\hline Interpret income statement & & $\sqrt{ }$ & & \\
\hline Interpret tax reports & & $\sqrt{ }$ & & \\
\hline Prepare forecasted income statement & & & $\sqrt{ }$ & \\
\hline Analyse forecasted variance on income statement & & & & $\sqrt{ }$ \\
\hline Prepare break-even analysis & & $\sqrt{ }$ & & \\
\hline Prepare segmented income statement & & $\sqrt{ }$ & & \\
\hline \multicolumn{5}{|l|}{ Working capital management } \\
\hline Prepare list of all debtors & $\sqrt{ }$ & & & \\
\hline Assess the levels of stock of the business & $\sqrt{ }$ & & & \\
\hline Prepare list of all creditors & $\sqrt{ }$ & & & \\
\hline Prepare cash flow statement & $\sqrt{ }$ & & & \\
\hline Prepare forecasted cash flow statement & & & $\sqrt{ }$ & \\
\hline Analyse cash flow statement using previous periods as a base & & & & $\sqrt{ }$ \\
\hline Budget/Forecast Variance analysis on cash flow statement & & & $\sqrt{ }$ & \\
\hline
\end{tabular}




\begin{tabular}{|l|l|l|l|l|}
\hline Analyse bank statements using previous periods as a base & \multicolumn{2}{|l|}{} & \multicolumn{1}{|l|}{} \\
\hline Asset and liability management & & & $\sqrt{ }$ & \\
\hline Prepare balance sheet & & & $\sqrt{ }$ & \\
\hline Prepare forecasted balance sheet & & & & $\sqrt{ }$ \\
\hline Analyse balance sheet using previous periods as a base & & & $\sqrt{ }$ & \\
\hline Budget/Forecast variance analysis on balance sheet & & & & $\sqrt{ }$ \\
\hline Analyse key financial ratios in the business & & & & \\
\hline Strategic financial management & & & $\sqrt{ }$ & \\
\hline Prepare business plans & & & $\sqrt{ }$ & \\
\hline Perform scenario analysis \& planning & & & & \\
\hline
\end{tabular}

(Source: own compilation)

From Table 3 and the relevant literature reviewed, it can be inferred that the identified financial management skills can be related to financial management practices which are all necessary for a successful business. Bruwer (2010:69) highlighted the importance of profitability management and states that retail SMEs experience difficulty in interpreting and analysing accounting information. Perks and Smith (2008:155) list debtors account management and inventory management as major potential problem areas in SMEs. García-Teruel and Martínez-Solano (2007:175) and Orobia (2013:226) regard the management of inventory and accounts receivable (working capital) as important for SMEs. This confirms that profitability management and working capital management skills are important to the success of an SME. Asset and liability management, as well as strategic financial management are listed as areas that require development within SMEs (Rajaram \& O’Neill, 2009:115; Schwarze, 2008:145).

\section{PROFILE OF THE WESTERN CAPE}

The target population in this study are SMEs in the Western Cape, the most South Western province of South Africa. Although the Western Cape has only about 11 percent of South Africa's population, it contributes nearly 15 percent of the South African GDP (Herrington \& Kew, 2013:56). Sixty percent of Western Cape businesses have medium to high growth perceptions compared to 38 percent in Gauteng and only 26 percent for the rest of South Africa. The Western Cape has the 
lowest unemployment figure at 21 percent compared with 26 percent for Gauteng and 38 percent for the Eastern Cape and Limpopo. These numbers illustrate that the Western Cape may be more accommodating towards entrepreneurs than some other South African provinces.

Different industries contribute different percentages to the Western Cape's regional GDP, as illustrated in Figure 3. Similarly, various districts in the Western Cape contribute different percentages to the regional GDP, as illustrated in Table 4. Naturally all these industries and districts need to be represented in the sample for this study.

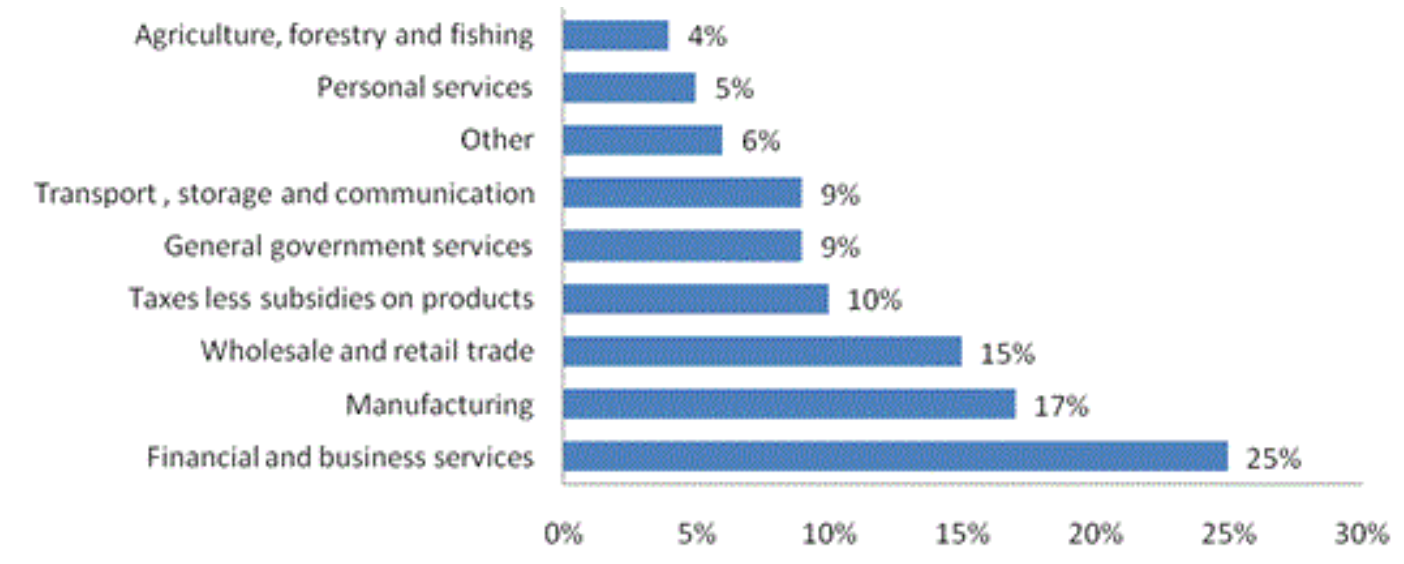

Figure 3: Percentage contribution per industry to Western Cape GDP

(Source: Adapted from Statistics South Africa, 2006:71)

Table 4: Contribution of the Western Cape districts to the South African GDP and Western Cape GDP

\begin{tabular}{|l|l|l|}
\hline Western Cape Region & $\begin{array}{l}\text { Share of South } \\
\text { African GDP } \\
\text { (\%) }\end{array}$ & $\begin{array}{l}\text { Share } \\
\text { Western Cape } \\
\text { GDPR (\%) }\end{array}$ \\
\hline Cape Town & $11.2 \%$ & $76.6 \%$ \\
\hline Cape Winelands & $1.5 \%$ & $10.5 \%$ \\
\hline Eden & $0.9 \%$ & $6.1 \%$ \\
\hline West Coast & $0.6 \%$ & $4.0 \%$ \\
\hline Overberg & $0.3 \%$ & $2.4 \%$ \\
\hline Central Karoo & $0.1 \%$ & $0.5 \%$ \\
\hline Total & $\mathbf{1 4 . 6 \%}$ & $\mathbf{1 0 0 . 0} \%$ \\
\hline
\end{tabular}

(Source: Adapted from Western Cape provincial treasury, 2006:217) 
Studies of the level of use of financial management practices in various parts of the country have confirmed that SMEs all over South Africa experience problems with the adequate application and use of these practices. These studies cover SMEs in Kwa-Zulu Natal (Rajaram \& O'Neill, 2009:99), Gauteng and the Eastern Cape (Van Eeden et al., 2003:13) and the Western Cape (Bruwer, 2010:69). However, none of these studies focused on the use of specific financial management practices by the owner-managers of SMEs, nor on the frequency with which these practices are used.

\section{HYPOTHESES AND RESEARCH METHODOLGY}

The relevant hypotheses of this study are:

Hypothesis 1 states that there are differences in the use of financial management practices by the owner-managers of successful SMEs in the Western Cape. Hypothesis 2 states that there are differences in the frequency with which the practices are voluntarily performed.

Hypothesis 3 speculates that it may be true, due to the high risk and volatile environment of SMEs, as well as the challenges that are often underestimated, that all the financial practices that academics regard as important are not always implemented by these companies.

Note that Hypothesis 2 covers practices that are voluntarily performed. It could be argued that some activities may be compulsory such as submitting VAT returns or other activities that might enhance financial management and control. For the purpose of this study it is assumed that the impact of such compulsory activities will not affect the results and conclusions of the study to a significant degree. The role of the regulatory environment and compliance should be acknowledged, but for the current purpose the impact of this role is assumed to be negligible.

A complete list of all SMEs in the Western Cape is not available. Therefore a judgemental sample of 30 of the most successful SMEs was taken from 150 suitable candidates from the records of an accounting firm engaged in providing financial management consultation to SMEs. Saunders, Lewis and Thornhill (2009:235) contend that for non-probability sampling, a minimum sample of between 25 and 30 
respondents should be used. Taking into account the sample sizes of between eight and 1036 respondents used by similar studies (see Table 1), a sample of 30 was deemed to be sufficient for this study.

The questionnaire consisted of two sections. The first section covered the demographic attributes of respondents. This information is included to ensure that the firm qualified to participate in the study. The second section of the questionnaire allowed respondents to indicate whether the financial management practices were used in the firm and the frequency thereof. Ethical concerns were addressed by a letter of consent that respondents completed during personal contact with the researcher, when they agreed to participate in the survey. If a respondent agreed to participate, the electronic link of the questionnaire's website was sent to him, with a specific username and password in order to complete the questionnaire at his own convenience. Each respondent was allowed to complete the questionnaire once only. On completion, the website then sent the answers to a centralised database that the researcher could access, in order to guarantee anonymity. To ensure completeness, the website had built-in controls to ensure that all questions were answered before it was submitted. To ensure accuracy, the website displayed the answers to the respondent before submitting them.

\section{RESULTS}

\section{Respondent characteristics}

The main characteristics of respondents are shown in Figures 4,5 and 6. All respondents conformed to the requirements of the study, namely they had already traded for at least three- and- a- half years, they had no more than 50 full-time employees and they had an annual turnover of no more than R14 million. 


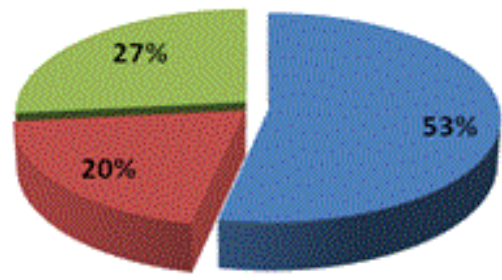

$$
\begin{aligned}
& =\text { Between } 1 \text { and } 5 \text { million rand } \\
& =\text { Between } 5 \text { and } 14 \text { million rand } \\
& =\text { Less than } 1 \text { million rand }
\end{aligned}
$$

Figure 4: Turnover per respondent

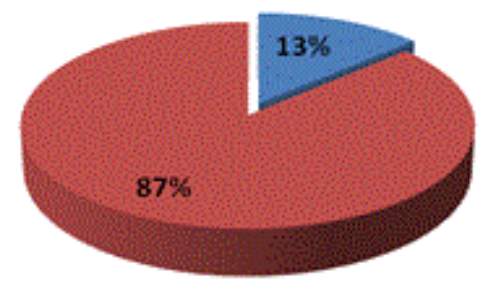

$$
\begin{aligned}
& \text { E Between } 10 \text { and } 50 \text { employees } \\
& \text { = Less than } 10 \text { employees }
\end{aligned}
$$

Figure 5: Number of employees per SME

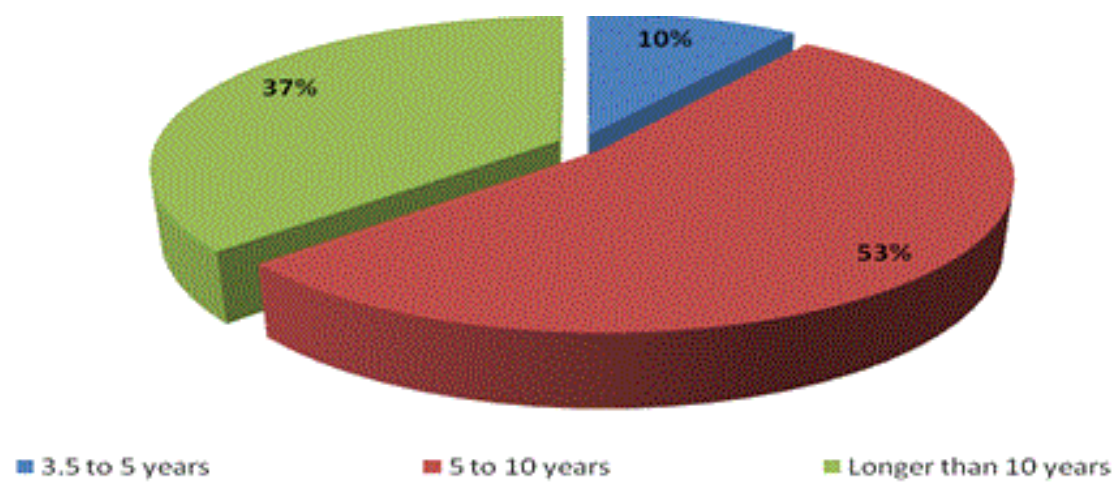

Figure 6: Number of years the SMEs traded 
From Figures 4, 5 and 6 it follows that the typical respondent had a turnover of between one and five million rand per year, had less than 10 employees, and had already traded between five and ten years.

\section{Representative industries and districts}

In Figure 3 the contribution of different industries to the Western Cape GDP is indicated. Following this, the percentage of this study's respondents per industry is given in Figure 7. The three main industries, namely wholesale and retail (50 percent), financial and business services (37 percent) and manufacturing (7 percent) were in total represented by 93 percent of the respondents.

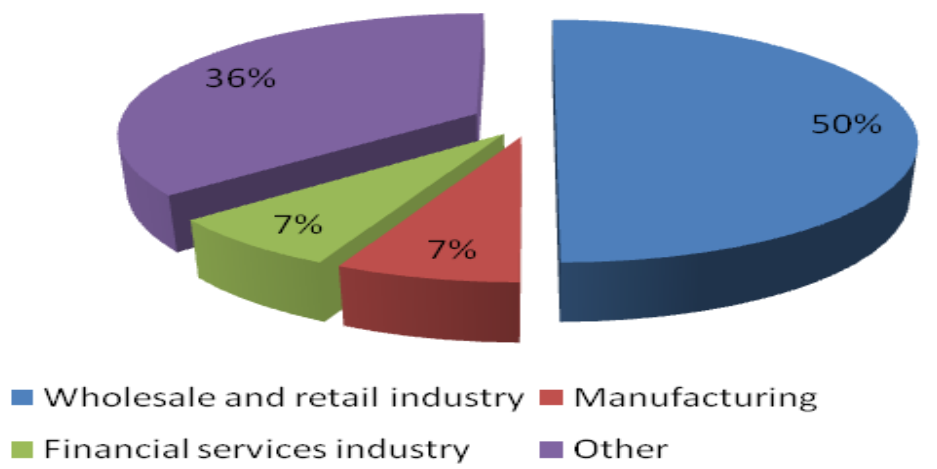

Figure 7: Respondents by industry

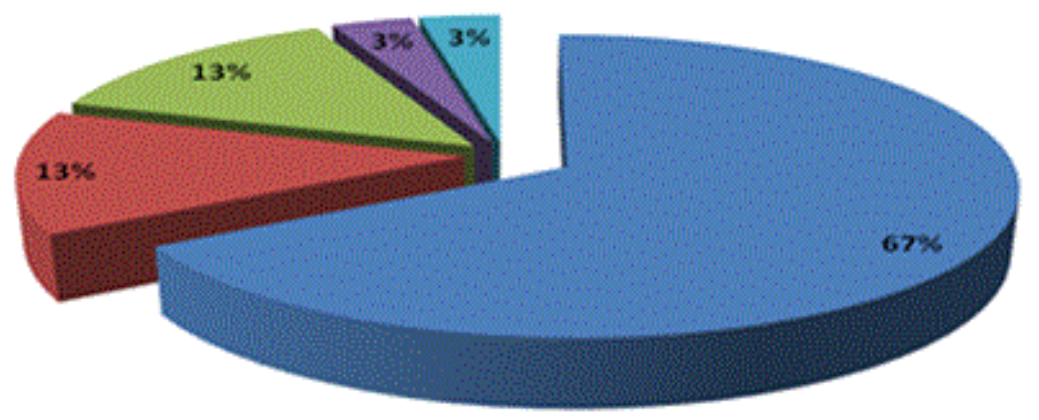

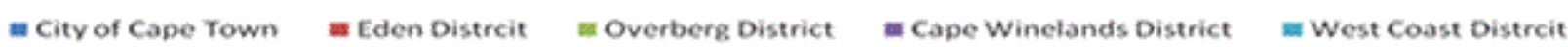

Figure 8: Geographical location of respondents 
In Figure 8 the geographical distribution of respondents is given. The same structure of representation as the distribution of the regional GDP (see Table 4) is evident here. Whereas the district of the City of Cape Town was represented by nearly 70 percent of the respondents, the other districts had fewer respondents.

The main results of the study are summarised in Table 5. The different financial management practices are linked to the financial topics (see Table 2), as well as to different financial management skills (see Table 3). The use of the practices is indicated by the percentage of respondents that perform them at all. Similarly the percentages of respondents who voluntarily perform the practice more than once per quarter, are also indicated. In the last column the weighted averages are given per financial practice, which could be used as an approximation of the relevance of the practices. In Table 5 the practices are ranked in decreasing order of relevance.

\section{Table 5: Ranking of financial practices by average of use and voluntary performance more than once every quarter}

\begin{tabular}{|c|c|c|c|c|c|c|}
\hline $\begin{array}{l}\text { Ra } \\
\text { nki } \\
\text { ng }\end{array}$ & Financial practice & $\begin{array}{l}\text { Financial } \\
\text { management } \\
\text { topic }\end{array}$ & $\begin{array}{l}\text { Financial } \\
\text { management } \\
\text { skill }\end{array}$ & $\begin{array}{l}\text { Percentage of } \\
\text { respondents } \\
\text { who perform } \\
\text { this practice }\end{array}$ & $\begin{array}{l}\text { Percentage } \\
\text { respondents } \\
\text { who perform } \\
\text { this practice } \\
\text { voluntarily } \\
\text { more than once } \\
\text { per quarter }\end{array}$ & $\begin{array}{l}\text { Weighted } \\
\text { average }\end{array}$ \\
\hline 2 & Prepare list of creditors & Working capital & Cash flow & 93 & 93 & 93 \\
\hline 3 & Interpret income statement & Profitability & Decision making & 90 & 67 & 78 \\
\hline 4 & Determine stock levels & Working capital & Cash flow & 78 & 65 & 72 \\
\hline 8 & Determine break-even point & Profitability & Decision making & 76 & 45 & 60 \\
\hline 9 & $\begin{array}{l}\text { Prepare segmented income } \\
\text { statement }\end{array}$ & Profitability & Decision making & 64 & 50 & 57 \\
\hline 10 & Prepare forecast income statement & Profitability & Planning & 83 & 30 & 57 \\
\hline 11 & $\begin{array}{l}\text { Compare actual to forecast income } \\
\text { statement }\end{array}$ & Profitability & Planning & 77 & 30 & 53 \\
\hline 12 & Prepare forecast cash flow statement & Strategic finance & Planning & 70 & 37 & 53 \\
\hline
\end{tabular}




\begin{tabular}{|c|l|l|l|l|l|l|}
\hline 13 & Compare actual with past cash flow & Working capital & Analyse & 60 & 40 & 50 \\
\hline 14 & Analyse bank statement & Working capital & Analyse & 60 & 33 & 47 \\
\hline 15 & Prepare scenario analysis & Strategic finance & Planning & 77 & 13 & 45 \\
\hline 16 & $\begin{array}{l}\text { Compare actual with forecast cash } \\
\text { flow }\end{array}$ & Working capital & Planning & 57 & 30 & 43 \\
\hline 17 & $\begin{array}{l}\text { Compare actual to past balance } \\
\text { sheets }\end{array}$ & Balance sheet & Analyse & 67 & 38 \\
\hline 18 & Perform financial ratio analysis & Balance sheet & Analyse & 53 & 10 & 32 \\
\hline 19 & Calculate financial ratios & Balance sheet & Analyse & 53 & 10 & 32 \\
\hline 20 & Prepare forecast balance sheet & Strategic finance & Planning & 43 & 7 & 25 \\
\hline 21 & Prepare business plan & Strategic finance & Planning & 43 & 3 \\
\hline
\end{tabular}

(Source: own compilation)

From Table 5 it can be concluded that there are definite differences in the percentage of respondents that use the financial management practices. This confirms Hypothesis 1 concerning the differences in the use of financial management practices. If one investigates the top five financial practices on this list, those involving working capital and cash flow feature prominently. This confirms the importance of regular information regarding cash flow for the owner-manager and the important role that working capital plays in the success of the SME (GarcíaTeruel \& Martínez-Solano, 2007:164).

If one investigates the bottom five financial management practices on this list, it can be seen that to analyse and to plan, to use the balance sheet and to engage in strategic financial activities are not used as much by the SMEs. It is cause for concern that some of these practices are performed by only 43 percent of the respondents. On the one hand one could say that respondents regard it as unnecessary to prepare a business plan or forecast a balance sheet on a regular basis, which are clearly much less relevant than, for instance, the management of cash flow. On the other hand one should take note of the fact that fewer than half of respondents ever perform these activities.

Table 5 also shows that there are differences in the percentages of respondents who voluntarily perform the practices more than once per quarter. This confirms 
Hypothesis 2 concerning the differences in the frequency with which the practices are voluntarily performed. Hypothesis 3 is as yet unanswered and leaves one with the question: Is it perhaps true that SMEs do not use all the financial practices that academics regard as important, due to the high risk and volatile environment of SMEs, as well as the challenges that are often underestimated? This could be true, but enough evidence does not appear in this study.

From Table 5 the averages of practices per financial management topic were calculated and are given in Table 6. Similarly the averages of practices per financial management skill are given in Table 7 .

Table 6: Ranking by financial management topic

\begin{tabular}{|l|l|l|l|l|}
\hline Ranking & $\begin{array}{l}\text { Financial } \\
\text { management } \\
\text { topic }\end{array}$ & $\begin{array}{l}\text { Average } \\
\text { percentage } \\
\text { respondents } \\
\text { who perform } \\
\text { this practice }\end{array}$ & $\begin{array}{l}\text { Average percentage } \\
\text { respondents who } \\
\text { perform this practice } \\
\text { voluntarily more than } \\
\text { once per quarter }\end{array}$ & $\begin{array}{l}\text { Weighted } \\
\text { average }\end{array}$ \\
\hline 1 & Working capital & 75 & 60 & 68 \\
\hline 2 & Profitability & 82 & 42 & 62 \\
\hline 3 & Balance sheet & 66 & 16 & 41 \\
\hline 4 & Strategic finance & 54 & 8 & 31 \\
\hline
\end{tabular}

Table 7: Ranking by financial management skill

\begin{tabular}{|l|l|l|l|l|}
\hline Ranking & $\begin{array}{l}\text { Financial } \\
\text { management } \\
\text { skill }\end{array}$ & $\begin{array}{l}\text { Average } \\
\text { percentage } \\
\text { respondents } \\
\text { who perform } \\
\text { this practice }\end{array}$ & $\begin{array}{l}\text { Average percentage } \\
\text { respondents who } \\
\text { perform this practice } \\
\text { voluntarily more than } \\
\text { once per quarter }\end{array}$ & $\begin{array}{l}\text { Weighted } \\
\text { average }\end{array}$ \\
\hline 1 & $\begin{array}{l}\text { Cash flow } \\
\text { management }\end{array}$ & 87 & 80 & 84 \\
\hline 2 & Decision making & 80 & 48 & 64 \\
\hline 3 & Planning & 64 & 21 & 43 \\
\hline
\end{tabular}




\begin{tabular}{|l|l|l|l|l|}
\hline 4 & Analysis & 59 & 21 & 40 \\
\hline
\end{tabular}

From Table 6 it can be concluded that practices regarding working capital as well as profitability are much more relevant than those regarding a balance sheet or strategic finance. Similarly, one could conclude from Table 7 that practices related to cash flow and decision making are more relevant than those related to planning or analysing.

\section{LIMITATIONS AND AREAS IN NEED OF FUTURE RESEARCH}

This study was limited to SMEs in the Western Cape. Future studies may investigate whether the same relationships hold for SMEs in other provinces. Secondly, no claim can be made that causality was proven. One cannot assume that these SMEs only became successful because they used these financial management practices; many other variables could also have played a role. Future research could investigate whether less successful SMEs have a different pattern of use of these financial management practices in order to understand more fully the relationship between these practices and SME success. Thirdly, future research could investigate whether SMEs could be even more successful if they would better understand the important role that analysing, planning, the balance sheet and strategic financial activities could play in their firms. Lastly, it should also be pointed out that there could be a bias in the type of SME that participated in the survey. The fact that these SMEs were clients of a management consulting firm could mean that they already conformed to certain requirements, such as being registered for tax, while they certainly realised the importance of financial advice. Future research might also focus on the relationships between financial practices and other variables where SMEs do not receive assistance from financial consultants. Could it be true that the high risk and volatile environment of SMEs, as well as the challenges that are often underestimated, are the main reasons that most financial practices that academics regard as important are not always utilised by these companies? Future research could address this issue. 


\section{CONCLUSIONS AND RECOMMENDATIONS}

The aim of this study is to identify which specific financial management practices are the most relevant to successful SMEs. It has now been established that financial management practices regarding working capital and profitability are more relevant to the owner-managers of established SMEs than those regarding balance sheets and strategic financial management. Practices regarding cash flow and decision making are also much more relevant than those regarding planning and detail analysis. It seems that to focus on short-term management issues like cash flow, is much more relevant for established SMEs than to have a medium to long-term view of the firm. On the other hand it could be argued that these firms became successful SMEs because they had a stronger focus on short-term management issues than on medium- to long-term aspects.

A number of recommendations can be made from this study. Firstly, nascent entrepreneurs and owner-managers of young SMEs should take note of the financial management practices that established SMEs have found to be most helpful. Secondly, educators of these entrepreneurs should take note of these rankings of practices by respondents. Thirdly, one could speculate whether these SMEs would not perhaps have been even more successful if they had, in fact, placed a higher focus on analysing and planning, or given more attention to understanding balance sheet items or engaging in strategic financial activities. This study contributes to a better understanding of which specific financial management practices are the most relevant to successful SMEs.

\section{REFERENCES}

Adeniran, T.V. \& Johnston, K.A. 2012. Investigating the dynamic capabilities and competitive advantage of South African SMEs. African Journal of Business Management, 6(11):4088-4099.

Akande, O.O. 2011. Accounting skill as a performance factor for small businesses in Nigeria. Journal of Emerging Trends in Economics and Management Sciences, 2(5):372-378.

Badenhorst-Weiss, J.A. \& Cilliers, J.O. 2014. Competitive advantage of independent small businesses in Soweto. Southern African Business Review, 18(3):1-21. 
Benzing, C., Chu, H. M. \& Kara, O. 2009. Entrepreneurs in Turkey: a factor analysis of motivations, success factors, and problems. Journal of Small Business Management, 47(1):58-91.

Berger, A.N. \& Udell, G.F. 1998. The economics of small business finance: the roles of private equity and debt markets in the financial growth cycle. Journal of Banking and Finance, 22(6):613-673.

Bezuidenhout, A. \& Nenungwe, A.L. 2012. A competency framework for the small business sector in Johannesburg, South Africa. African Journal of Business Management, 6(47): 11658-11669.

Bloom, J.Z. \& Boessenkool, A.L. 2002. Financial management. in Nieman, G. and Bennett, A. (Eds). Business management: a value chain approach. pp. 205-256. Pretoria: Van Schaik.

Brigham, E. F. \& Houston, J. F. 2011. Fundamentals of financial management, $7^{\text {th }}$ ed. Mason, Ohio: South Western.

Bruwer, J. 2010, Sustainability of South African FMCG SMME retail businesses in the Cape Peninsula, unpublished MTech thesis, Cape Town: Cape Peninsula University of Technology.

Burger, A. 2009. Small business definition changed. Tax Breaks Newsletter, 287:4-5. Carter, R. \& Van Auken, H. 2006. Small firm bankruptcy. Journal of Small Business Management, 44(4):493-512.

Chandra, P. 2008. Financial management. New Delhi: McGraw-Hill.

Collis, J. \& Jarvis, R. 2002. Financial information and the management of small private companies. Journal of Small Business and Enterprise Development, 9(2):100-110.

Cressy, R. 2006. Why do most firms die young? Small Business Economics, 26:103116.

Dennis, W.J. \& Fernald, L.W. 2001. The chances of financial success (and loss) from small business ownership. Entrepreneurship:Theory \& Practice, 26(1):75-83.

Everett, J. \& Watson, J. 1998. Small business failure and external risk factors. Small Business Economics, 11:371-390. 
García-Teruel, P.J. \& Martínez-Solano, P. 2007. Effects of working capital management on SME profitability. International Journal of Managerial Finance, 3(2):164-177.

Gorgievski, M., Ascalon, M.E. \& Stephan, U. 2011. Small business owners' success criteria, a values approach to personal differences. Journal of Small Business Management, 49(2):207-232.

Herrington, M. \& Kew, J. 2013. Global Entrepreneurship Monitor: South African report. [Online] available from http://www.gemconsortium.org/ [downloaded: 201502-17]

Knaup, A.E. \& Piazza, C.P. 2007. Business employment dynamics data: survival and longevity. Monthly Labour Review, 130(9):3-10.

Kotze, L. \& Smit, A.V.A. 2008. Personal financial literacy and personal debt management: the potential relationship with new venture creation. South African Journal of Entrepreneurship and Small Business Management, 1:35-50.

LeCornu, M.R., McMahon, R.G.P., Forsaith, D.M. \& Stanger, A.M.J. 1996. The small enterprise financial objective function. Journal of Small Business Management, 34(3):1-14.

Liang, T.W. 2003. What is an SME? SME definitions and statistical issues. Journal of Enterprising Culture, 11(3):173-183.

Ligthelm, A.A. 2010. Entrepreneurship and small business sustainability. Southern African Business Review, 14(3):131-153.

Marzocchi, C., Ramlogan, R. \& Gagliardi, D. 2013. A recovery on the horizon? Annual report on European SMEs. [Online] available from: http://ec.europa.eu [downloaded: 2015:02:17 ]

McMahon, R.G.P. \& Davies, L.G. 1994. Financial reporting and analysis practices in small enterprises: their association with growth rate and financial performance. Journal of Small Business Management, 32(1):1-17.

Moyer, R.C., McGuigan, J.R. \& Kretlow, W.J. 2012. Contemporary financial management. $12^{\text {th }}$ ed., Mason, Ohio: South Western.

Nkosi, E. Bounds, M. \& Goldman, G. 2013. Skills required for the management of Black-owned small enterprises in Soweto. Acta Commercii, 13(1), Art. \#186, 10 pages. http://dx.doi.org/10.4102/ac.v13i1.186. 
Olawale, F. \& Garwe, D. 2010. Obstacles to the growth of new SMMEs in South Africa: a principal component analysis approach. African Journal of Business Management, 4(5):729-738.

Olawale, F. \& Smit, A.V.A. 2010. The impact of the business environment on the availability of trade credit to new SMEs in South Africa. African Journal of Business Management, 4(9):1790-1799.

Orobia, L.A. 2013. Gender differences in working capital management amongst small business owners in Uganda. JJournal of Economics and Behavioural Studies, 5(4):226-236.

Perks, S. \& Smith, E.E. 2008. Focused training programmes for solving growth problems of very small businesses. Acta Commercii, 8:145-159.

Pretorius, M. 2009. Defining business decline, failure and turnaround: a content analysis. South African Journal of Entrepreneurship and Small Business Management, 2(1):1-16.

Radipere, S. \& Van Scheers, L. 2005. Investigating whether a lack of marketing and managerial skills is the main cause of business failure in South Africa. South African Journal of Economic and Management Sciences, 8(4):402-411.

Rajaram, R. \& O'Neill, C. 2009. Profit or no profit - does the SME sector really know? Alternation, 16(1):99-119.

Richard, P.J., Devinney, T.M., Yip, G.S. \& Johnson, G. 2009. Measuring organizational performance: towards methodological best practice. Journal of Management, 35(3):718-804.

Rogerson, C.M. 2001a. Growing the SMME manufacturing economy in South Africa: evidence from Gauteng province. Journal of Contemporary African Studies, 19(2):267-291.

Rogerson, C.M. 2001b. Towards a framework for rural SMME development in South Africa. in Khosa, M. (Ed.). Empowerment through economic transformation. Durban: African Millennium Press, pp. 271-298.

Rogerson, C.M. 2008. Tracking SMME development in South Africa: issues of finance, training and the regulatory environment. Urban Forum, 19:61-81.

Roodt, J. 2005. Self-employment and the required skills. Management Dynamics, 14(4):18-33. 
Rootman, C. \& Kruger, J. 2010. Adapting SMME business functions during economic turmoil. Acta Commercii, 10:107-119.

Sanda, A., Sackey, J. \& Fältholm, Y. 2011. Managerial competence and nonperformance of small firms in a developing economy. International Journal of Contemporary Business Studies, 2(3):6-24.

Saunders, M., Lewis, P. \& Thornhill, A. 2009. Research methods for business students. $5^{\text {th }}$ ed., Harlow, Essex: Pearson.

Schwarze, C. L. 2008. Involving the accounting profession in the development of financial management skills of micro-enterprise owners in South Africa. Meditari Accountancy Research, 16(2):139-151.

South Africa. 1996. National Small Business Act No. 102. Pretoria: Government Printer.

Statistics Canada. 1997. Failing concerns: business bankruptcy in Canada. Ottawa: Statistics Canada.

Statistics South Africa. 2006. Provincial Profile 2004: Western Cape. Pretoria: Statistics South Africa.

Steyn, A.A. \& Leonard, A.C. 2012. Guidance for SMEs with the adoption of technology: a conceptual framework. South African Journal of Entrepreneurship and Small Business Management, 5:24-33.

Thomas, J. \& Evanson, R.V. 1987. An empirical investigation of association between financial ratio use and small business success. Journal of Business Finance \& Accounting, 14(4):555-571.

Turton, N. \& Herrington, M. 2012. Global Entrepreneurship Monitor: South Africa. [Online] available from http://www.gemconsortium.org/ [downloaded: 2015-02-17]. Van Eeden, S., Viviers, S. \& Venter, D. 2003. A comparative study of selected problems encountered by small business in the Nelson Mandela, Cape Town and Egoli metropoles. Management Dynamics, 12(3):13-23.

Von Broembsen, M., Wood, E. \& Herrington, M. 2005, Global Entrepreneurship Monitor South Africa 2005, [Online] available from: http://bbbee.typepad.com/ paul_janisch/files/GEM2005.pdf [downloaded:2011-07-01].

Walker, E. \& Brown, A. 2004. What success factors are important to small business owners? International Small Business Journal, 22(6):577-594. 
Watson, G. E. H. 2004, A situational analysis of entrepreneurship mentors in South Africa, unpublished Masters of Commerce thesis, University of South Africa, Pretoria.

Western Cape Provincial Treasury. 2006. Provincial Economic Review \& Outlook. Pretoria: Business Print Centre.

World Bank. 2011. Small and medium enterprises: A cross-country analysis with a new data set. [Online] available from: http://www-wds.worldbank.org/external/ default/WDSContentServer/WDSP/IB/2011/01/18/000158349_20110118141007/Ren dered/PDF/WPS5538.pdf [downloaded 2011-07-10].

Xesha, D., Iwu, C.G. \& Slabbert, A. 2014. Business relationships as a driver of success for small, medium, and micro enterprises (SMMEs) in South Africa. Journal of Economics, 5(1):37-43. 